\title{
Marketing Communication and Its Impact on Purchase Willingness and Unwillingness: A Case of a Boycotted Bread Brand
}

\author{
U. Suhud \\ Universitas Negeri Jakarta \\ Jakarta, Indonesia
}

\begin{abstract}
The Muslim consumers in Indonesia who involved in several political street protests, boycotted a bread brand as the producer of this bread refused to be associated with their activities. This study aims to examine the impact of animosity on boycott participation, boycott motivation, attitude towards marketing communication, and purchase willingness and unwillingness of this boycotted bread brand. The author chose participants of this current study conveniently, and in total, 266 participants took part consisting of 167 females and 99 males. The data were analysed using exploratory and structural equation model. This study tested eight hypotheses, and all of them were significant. As a result, animosity had a significant effect on boycott motivation, boycott participation intention, and attitude towards marketing communication. Further, attitude towards marketing communication and boycott participation intention had a significant impact on purchase unwillingness and purchase willingness. This study discusses recommendations for practitioners and future research.
\end{abstract}

Keywords-animosity; marketing communication; purchase willingness;

\section{INTRODUCTION}

In general, bread is not the staple food of Indonesians. However, bread is consumed widely by consumers, both for breakfast and as a snack. Consumers buy bread, either to the bakery, the modern market or to the bread sellers who use the cart around. The bread sold have a brand. There are old brands but only known in specific areas only, and there is also a new brand widely known nationally. The bread brand referred to in this study is a nationally known bread brand and is considered a brand new bread even though it has been sold since 1996 [1]. Near the end of 2016, there were protests involving thousands of Muslims in Jakarta. They then held three protests urging the authorities to immediately prosecute the Governor of the Special Capital Region of Jakarta at the time who was accused of blasphemy. The demonstrators claimed that the events they held as pure action defended Islam, while many regarded those events as political events related to the 2017 governorship of Jakarta. At one of the protests, anonymous donors bought carts of bread from street vendors and gave the bread to the protesters. The protesters who did not know the actual story thought that the street vendors gave the bread as their initiation. Compliments were addressed to the vendors as if they were heroes who supported the protesters.

The vendors were affiliated with the national bread brand owned by a conglomerate. Avoiding being associated with political events, the bread producer announced on their website. This marketing communication sparked outrage from the demonstrators. As a result, the protesters made a call to boycott the brand.

Scholars have paid attention to the cases of consumer boycotts. For example, the British oil company, BP, spilt crude oil in the Gulf of Mexico [2] and a magazine in Denmark that illustrated the contempt of the Prophet Muhammad [3]. Further, [4] looks at the boycott of KFC restaurant, [5] focus on the Israeli products boycott, and [6] who studied anti-apartheid in England.

This study aims to test the effect of animosity, boycott motivation, intention to boycott participation, and attitude towards a marketing communication on purchase willingness and purchase unwillingness. In this current study, the marketing communication refers to an announcement published by a company popping up on their website page. The object of this research is a brand of the bread boycotted by Muslim consumers.

This research will bring innovations. There is a paucity of research on consumer boycotts, firstly, about food products, especially bread. Second, involves consumer attitudes toward marketing communication. Third, methodologically, in this study, the authors measure the purchase willingness and purchase unwillingness in a research model.

\section{A. Consumer animosity}

[7] define animosity as "remnants of antipathy related to previous or ongoing military, political or economic events". This definition is inspired by the anger of Chinese at Japan, Japanese, and Japanese products. Prior studies use animosity to predict purchase action and boycott participation [8] [9]. It also affects brand attitude, product judgment, and ethnocentrism [10] [11]. Animosity is also used to predict purchase willingness and unwillingness [11] [12]. In this study, animosity is linked to attitude toward marketing communication, boycott participation, and boycott motivation.

\section{B. Boycott motivation}

Everyone might have a reason to pro or against a brand or company. Those who against, at some point, could express their selves by participating in a boycott. To be involved in a boycott, consumers might have a motivation [5] and boycott motivation apparently, is still new research area to be explored [13].

Some factors might motivate consumers at a boycott [14]. [14] group motivation into dimensions including expressive, 
instrumental, 'clean hands' and 'others' to represent other reasons. Express dimension is when consumers expressively show their anger at the company while instrumental dimension is about using their power to punish the company. Additionally, 'clean hands' relates to the feeling good caused by boycotting the company. In the study of [15], these dimensions have an important role in enhancing consumers' perceived likelihood of boycott success. Although some studies demonstrate dimensions of boycott motivation, on the other hand, other scholars show boycott motivation without any dimension [16] [17].

In a study undertaken by [5], boycott motivation is used to measure consumer participation in boycotting Israeli products in Indonesia. The cause was not affected by Israeli companies, but in many cases, the boycott is stimulated by companies' operational [18] [19] [20] [21]. However, instead of pointing the cause stimulated by a corporate mistake, [22] look at the psychological process, particularly motivation, as a predictor to affect consumer decision to participate in a boycott. They claim that "consumers' participation in a boycott is a function of their perception of expectancy that their collective effort will lead to the achievement of boycott objectives and their perception of instrumentality that the achievement of boycott objectives will lead to valued outcomes". Further, [21] argue that boycott motivation is a result of social factors, such as message credibility, expected overall participation, and perceived boycott effectiveness.

\section{Attitude towards marketing communication}

Sari Roti is the Indonesian boycotted bread brand in the last of 2016 by the street protesters in the case of blasphemy of the Governor of Jakarta at that moment. The producer announced on the company's website stating that the company had nothing to do with the activities of the protesters. Of course, the company did not have a prediction that what it did was deemed to hurt the protesters until they called for a boycott.

According to [23], there are three types of communication held by a corporate, including corporate communication, marketing communication, and organisational communication, and they are parts of corporate identity. As it deals with consumers, the communication made by the company on its website can be called as a marketing communication. One of the marketing communication activities is advertising [24]. Advertising that hurts its customers can be considered as offensive advertising.

Scholars [25] [26] [27] have studied the attitude of viewers on the advertisement of controversial products. The controversial products include racially extremist groups, religious denominations and female hygiene products as well as cigarettes, political parties, alcohol, and male underwear [27]. However, bread in the case of this current study is not a controversial product. As mentioned earlier, it was about the advertisement content that was perceived impropriate and offensive. An advertisement is considered offensive if it includes racist, anti-social behaviour, sexist, subject too personal, indecent language, and nudity. According to Asian viewers, an advertisement is considered offensive if it contains sexual connotations, a subject too personal, evoking unnecessary fear, cultural insensitivity, indecent language, sexist attitude, and nudity. However, each viewer might have a different reaction once they watch an advertisement that is categorised offensive. The factors to differentiate are culture [25] and religion [26] [28]

\section{Boycott participation}

As defined by [29], consumer boycott is "an attempt by one or more parties to achieve certain objectives by urging individual consumers to refrain from making selected purchases in the marketplace". [30] identify categories of consumer boycott as primary, secondary, and tertiary as well as voluntary, direct, indirect, substitution, and expressive boycotts. Further, [31] look at the type of boycott participation. According to them, boycott participation consists of complaint to the company, stops purchasing, acceptable alternate product, and word of mouth, as well as organises citizen's action, online word of mouth, and legal action.

\section{E. Theoretical framework}

[5] links animosity on product judgment, boycott participation, and boycott motivation in his study to test the willingness and unwillingness Indonesian consumers to purchase Israeli product. This study is in response to the boycott declared by Organisation of Islamic Cooperation in March 2016. This scholar finds a significant impact of animosity on product judgment, boycott participation, and boycott motivation.

A Chinese study is conducted by [32]. They investigate the impact of ethnocentrism and animosity on attitude towards Chinese, Japanese, and European fashion brands. One of the findings they carries out was that economic animosity had a negative effect on the brand attitude of the Japanese brand.

Further, [33] study factors influencing attitude towards offshore outsourcing in North America by employing consumer ethnocentrism, beliefs toward quality, cultural openness, animosity, economic threat, and patriotism as predictor variables. Offshore outsourcing, as defined by the scholars, is "when U.S. firms hire service providers in foreign countries to perform functions that were once done by the U.S. firms. Examples include IT, Call Centre Management...". As a result, they mention a negative impact of animosity on attitude.

There is a paucity of study employing consumers' attitude towards marketing communication. Therefore, this study adapt attitude in general in different areas of a marketing study. For example, [34] test the global brand attitude relating to BP oil company after an incident in Mexico Gulf. They involve participants in three different countries including Brazil, Germany, and South Korea. The study shows a significant and negative impact of global company animosity on global brand attitude in the case of Germany and Brazil whereas in South Korea was insignificant.

Based on the results of the literature review above, the following hypotheses are made:

$H_{1}$-Animosity had a significant and positive impact on boycott motivation. 


\section{METHOD}

$\mathrm{H}_{2}$-Animosity had a significant and positive impact on boycott participation.

$\mathrm{H}_{3}$-Animosity had a significant and negative impact on attitude towards marketing communication.

A study conducted by [5] measures the intention of Muslim consumers to participate in a movement to boycott Israeli product. The scholar employs animosity, product judgment, and boycott motivation as predictor variables. One of the results saying that there is a significant effect of boycott motivation on boycott participation.

$\mathrm{H}_{4}$-Boycott motivation will have a significant and positive impact on boycott participation.

[35] use the theory of planned behaviour by employing attitude, subjective norms and affordability. That study is addressed to predict willingness of customers to purchase organic food. These scholars show a significant effect of attitude and subjective norm on purchase willingness.

In the wine industry set, [36] involve members of the society of wine educators across nations to examine their willingness to purchase wine. In their study, they link attitude on purchase willingness. As a result, attitude has a significant impact on willingness to purchase wine.

A Chinese' study is conducted by [37] to examine consumers' purchase willingness of counterfeited smartphones. The purchase willingness is predicted by the attitude towards counterfeit product and perceived risk. This study carries out a result showing that attitude has a significant influence on willingness to purchase.

Therefore, given the above, for hypothesis 5 and 6 , the author proposes:

$\mathrm{H}_{5}$-Attitude towards marketing communication will have a significant and negative impact on purchase unwillingness.

$\mathrm{H}_{6}$-Attitude towards marketing communication will have a significant and positive impact on purchase willingness.

Boycott participation was employed in prior studies to measure purchase willingness [38] [39] and purchase unwillingness [17] [39]. In this study, boycott participation is linked to purchase unwillingness. In the study undertaken by [39], boycott participation was linked to the willingness and unwillingness to purchase Israeli products. In that study, boycott participation had two dimensions-'promote change' and 'I will better about myself'-that assessed separately in two models. Both dimensions negatively affected purchase willingness and positively affected purchase unwillingness.

Therefore, for hypotheses 7 and 8, the author proposes the following:

$H_{7}$-Boycott participation will have a significant and positive influence on purchase unwillingness.

$\mathrm{H}_{8}$-Boycott participation will have a significant and positive influence on purchase willingness.

Based on the review of the literature above, here is the proposed model to be tested.

\section{A. Sample}

Participants were approached conveniently using a personal communication through email and social media platforms, particularly chat applications, such as Line, Telegram, and WhatsApp. The authors obtained help from students to distribute the online instrument link to their networks. There was no specific filter for participants for being involved in the survey unless age restriction of 17 years old minimum.

In total, 266 participants involved in this current study consisting 167 females $(62,8 \%)$ and 99 males $(37.2 \%)$. The majority of participants, with a total of 198 people $(74.4 \%)$, lived in Jakarta. Participants who held senior high school diploma were 183 people $(68.8 \%)$, followed by those who held a bachelor degree (68 participants; 25.6\%). Furthermore, predominantly, participants were aged between 20 to 24 years with a total of 191 people $(71.8 \%)$. Concerning marital status, 244 participants $(92.9 \%)$ indicated that they were unmarried. Also, 137 participants (51.5\%) stated they were unemployed. This fact is well understood because they had recently graduated from high school and most likely they were still in college.

Most participants, amounting to 224 people (84.2\%), were Muslim. Then, 261 participants $(98.1 \%)$ experienced ever purchasing Sari Roti bread. Eighteen participants (6.8\%) said that they bought Sari Roti bread today, 79 participants $(29.7 \%)$ bought bread in this week, 66 participants (24.8\%) bought bread in this month. Moreover, 102 participants (38.3\%) said they did not remember the last time they bought Sari Roti bread. The last question the author asked was about how much they agreed or disagreed with the invitation to boycott Sari Roti Bread. A total of 66 participants $(24.8 \%)$ indicated agree, while 200 participants $(75.2 \%)$ said they did not agree to boycott.

\section{B. Measures}

There were five variables involved in this research. To measure these variables, the authors took indicators of existing studies. Animosity was measured by indicators adapted from [40]. Boycott motivation was examined by indicators translated and adapted from [41]. Then, attitude towards marketing communication was measured by indicators changed from [41], while boycott participation is taken and modified from [42] Klein et al. (2004). Furthermore, purchase willingness was measured by indicators adapted from [40] and [41]. All indicators equipped with six points Likert's scale consisted of 1 to strongly disagree with up to 6 to strongly agree. Instruments presented in Bahasa (language) Indonesia.

\section{Data analysis}

The author analysed the quantitative data collected in three phases. The first stage performs exploratory factor analysis. This stage aims to establish the dimensions of each variable if it exists and maintains valid indicators. The valid indicators should have factor loadings of 0.4 or more. According to Hair, if factor loadings are installed 0.4, then the participants must be at least 200 [44]. The second stage was to test the 
reliability. In this study, the authors selected factors that had a Cronbach's alpha value of 0.7 [44]. The third stage, testing the research model using structural equation model (SEM). A fitted model must have a probability value of 0.05 [45] and CMIN/DF value of $\leq 2$ [46] (Tabachnick \& Fidell 2007). Besides, a CFI value of $\geq 0.97$ [47] and RMSEA value of $\leq$ 0.05 (Hu \& Bentler 1999).

\section{RESULT}

\section{A. Exploratory factor analysis}

The exploratory factor analysis (EFA) calculation resulted from nine constructs (Table 1). Attitude towards marketing communication formed two constructs. The first construct had seven indicators with a Cronbach's alpha score of 0.941. It obtained factor loadings ranging from 0.793 to 0.979 . The second construct had two indicators consisting of 0.893 and 0.926. It had a Cronbach's alpha score of 0.837 .

The next construct was animosity which sustained four indicators with factor loadings ranging from 0.865 to 0.919 . This construct had a Cronbach's alpha score of 0.910 . Furthermore, boycott participation has two constructs. The first construct consists of seven indicators with factor loadings between 0.793 to 0.929 and Cronbach's alpha value of 0.949 . The second construct consisted of three indicators with factor loadings consisting of 0.556 to 0.838 . This second construct had a Cronbach's alpha value of 0.471 . Although this value was deemed to be less reliable, the author retained this construct. From the case of [48], constructs with such low values could help to form models that were fitted during later hypothesis testing.

Another variable that had two constructs was boycott motivation. The first construct had three indicators with factor loadings between 0.887 and 0.954 and Cronbach's alpha value of 0.922 . The second construct had two indicators with factor loadings of 0.853 and 0.823 respectively. The second construct had a Cronbach's alpha value of 0.581 . This value can also be considered to be less reliable. Nevertheless, the author retained it. The next construct was purchase willingness which held five indicators with factor loadings between 0.798 and 0.854. This construct had a Cronbach's alpha value of 0.883 . The final construct was purchase unwillingness. It had two indicators with factor loadings of 0.912 and 0.775 respectively. This construct had Cronbach's alpha value of 0.701 .

Table 1. EFA results.

\begin{tabular}{|l|l|l|}
\hline & \multicolumn{1}{|c|}{} & $\begin{array}{l}\text { Factor } \\
\text { Loadings }\end{array}$ \\
\hline 1 & $\begin{array}{l}\text { Attitude towards the marketing } \\
\text { communication (1) }\end{array}$ & 0.941 \\
\hline A6 & $\begin{array}{l}\text { The marketing communication made by Sari } \\
\text { Roti is objective }\end{array}$ & 0.879 \\
\hline A2 & $\begin{array}{l}\text { The marketing communication made by Sari } \\
\text { Roti is interesting }\end{array}$ & 0.867 \\
\hline
\end{tabular}

A5 The marketing communication made by Sari 0.853 Roti is easy to understand

A3 The marketing communication made by Sari 0.850 Roti is informative

A4 The marketing communication made by Sari 0.850 Roti is appropriate

A1 The marketing communication made by Sari 0.818 Roti is good

A7 The marketing communication made by Sari 0.793 Roti is special

2 Attitude toward the marketing communication $(2)(\alpha=0.837)$

A8 $\quad$ The marketing communication made by Sari 0.926 Roti is inappropriate *

A9 The marketing communication made by Sari 0.893 Roti is insulting *

\begin{tabular}{l|l|l}
\hline 3 & Animosity & 0.910
\end{tabular}

\begin{tabular}{l|l|l}
\hline AN2 I feel angry with the manufacturer Sari Roti & 0.919
\end{tabular}

AN3 I will not forget what Sari Roti producer has 0.885 done to the Muslims

AN4 Manufacturers of Sari Roti should pay what 0.882 they have done to Muslims

\begin{tabular}{l|l|l}
\hline AN1 I do not like the manufacturer of Sari Roti & 0.865
\end{tabular}

Table 1. Cont.

$4 \quad$ Boycott participation (1) $(\alpha=0.949)$

BP3 By boycotting Sari Roti product, I can0.929 change the manufacturer of Sari Roti

BP2 Everyone should take part to boycott Sari 0.926 Roti products

BP7 $\quad$ My friends/family support me to boycott 0.923 Sari Roti products

BP5 I would feel guilty if I bought Sari Roti0.900 products

BP4 I am angry, and I want the manufacturer Sari 0.851 Roti knows

BP6 I would be uncomfortable if people saw me 0.811 buy Sari Roti products

BP1 A boycott can effectively bring about change 0.793

$5 \quad$ Boycott participation (2) $(\alpha=0.471)$

BP8 Logically, I do not need to boycott Sari Roti0.838 products, let others do it

BP9 Buying SARI ROTI products will not be 0.680 known by others

BP12 By a boycott will make Sari Roti business 0.556 continuity in jeopardy

$6 \quad$ Boycott motivation (1) $(\alpha=0.922)$

M5 I would feel guilty if I bought Sari Roti0.954 products

M4 I want to punish Sari Roti by not buying 0.944 their products

M1 I would like to show my anger at Sari Roti0.887 manufacturer by avoiding buying Sari Roti products

$7 \quad$ Boycott motivation (2) $(\alpha=0.581)$

M2 Boycott Sari Roti products will not pressure 0.853 the manufacturer to change its policy on the marketing communication they have made 


\begin{tabular}{|l|l|l|}
\hline M3 & $\begin{array}{l}\text { I do not think that I should use the decision } \\
\text { to boycott Sari Roti products to voice my } \\
\text { opinion about defending my religion }\end{array}$ & \\
\hline 8 & Purchase willingness (1) $(\alpha=0.883)$ & \\
\hline W6 & $\begin{array}{l}\text { I would recommend to others to buy Sari } \\
\text { Roti products }\end{array}$ & 0.854 \\
\hline W7 & $\begin{array}{l}\text { I intend to buy Sari Roti products in the } \\
\text { future }\end{array}$ & 0.818 \\
\hline W3 & $\begin{array}{l}\text { Whenever available, I would prefer to buy } \\
\text { Sari Roti products }\end{array}$ & 0.801 \\
\hline W5 & $\begin{array}{l}\text { I will buy Sari Roti products from other } \\
\text { available bread brands }\end{array}$ & 0.801 \\
\hline W2 & $\begin{array}{l}\text { I like the idea of buying Sari Roti products } \\
\text { Purchase willingness (2) } \alpha=0.701)\end{array}$ & 0.798 \\
\hline 9 & $\begin{array}{l}\text { If there are two products of the same quality, } \\
\text { but one made by Sari Roti and the other } \\
\text { made by another company, I will be willing } \\
\text { to pay 10\% more expensive products made } \\
\text { by another company }\end{array}$ & \\
\hline W4 & $\begin{array}{l}\text { Wherever possible, I avoid buying Sari Roti } \\
\text { products }\end{array}$ \\
\hline Wro.775 \\
\hline
\end{tabular}

*Transformed.

\section{B. Hypotheses testing}

Figure 2 shows the structural model of the hypotheses testing. This model is considered fitted with a probability score of $0.058, \mathrm{CMIN} / \mathrm{DF}$ score of 1.260 , CFI score of 0.990 , and RMSEA score of 0.031 .

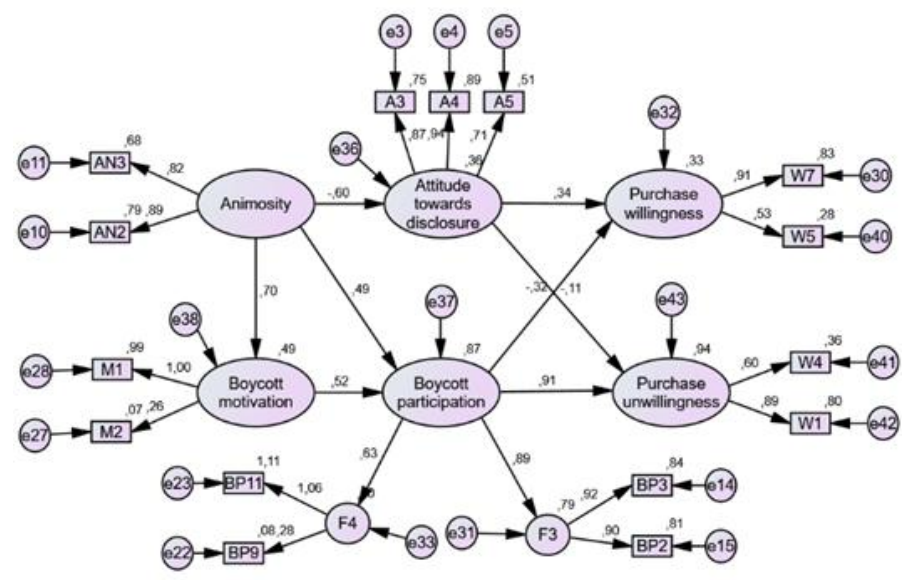

Fig. 1 Structural model of the theoretical framework testing

Table 2 shows the results of hypotheses testing. In total there were eight hypotheses tested, and all of them obtained C.R. score bigger than 1.96 indicating all of the paths were significant.

Table 2. Hypotheses testing results.

\begin{tabular}{|l|l|l|l|l|l|}
\hline & Paths & & & C.R. & P \\
\hline $\mathrm{H}_{1}$ & An & $\rightarrow$ & BM & 12.463 & $* * *$ \\
\hline $\mathrm{H}_{2}$ & An & $\rightarrow$ & BP & 3.601 & $* * *$ \\
\hline $\mathrm{H}_{3}$ & An & $\rightarrow$ & At & 9.697 & $* * *$ \\
\hline $\mathrm{H}_{4}$ & BM & $\rightarrow$ & BP & 2.924 & 0.003 \\
\hline
\end{tabular}

\begin{tabular}{|l|l|l|l|l|l|}
\hline & Paths & & & C.R. & P \\
\hline $\mathrm{H}_{5}$ & At & $\rightarrow$ & PU & -2.268 & 0.023 \\
\hline $\mathrm{H}_{6}$ & At & $\rightarrow$ & PW & 4.695 & $* * *$ \\
\hline $\mathrm{H}_{7}$ & BP & $\rightarrow$ & PW & 4.281 & $* * *$ \\
\hline $\mathrm{H}_{8}$ & BP & $\rightarrow$ & PU & 9.326 & $* * *$ \\
\hline
\end{tabular}

* Note:

An= Animosity

$\mathrm{BM}=$ Boycott motivation

$\mathrm{BP}=$ Boycott participation

$\mathrm{At}=$ Attitude towards marketing communication

PW= Purchase willingness

$\mathrm{PU}=$ Purchase unwillingness

\section{Discussion}

A little study has measured the role of animosity in influencing boycott motivation. [5] has documented, and this current study supports his finding. The first hypothesis predicted the impact of animosity on boycott motivation. This path was considered significant in a positive direction with a C.R. score of 12.463 . In general, dimensions of animosity consist of economic, people, political, religious, historical, and military [49]. In the case of this current study, political and religious dimensions apparently dominated motivating consumers to boycott.

Studies tested the impact of animosity on ethnocentrism, product judgment, purchase action, and willingness to pay [8] [11] [12]. However, less of them looked at the influence of this factor on boycott participation as [5] did. A finding of this current study in line with that. The second hypothesis measured the influence of animosity on boycott participation. This path had a C.R. score of 3.601 and indicated a significance. When someone is angry, a person may not use his or her common sense. Anger and resentment can be one of the triggers of a person participating in a boycott.

In consumer boycott study, the impact of animosity on attitude is also rare to have scholarly attention. In this current study, this path resulted a C.R. score of -9.697 . This finding reinforces prior studies [32] [33] even though they are not researching consumer boycott. Attitude is an affective factor that can be easily influenced by cognitive factors or other affective factors [50], such as anger and resentment. When this predictor factor works, the resulting attitude can be favourable or unfavourable depending on the person. If the attitude created is unfavourable because of the hatred of a brand, the predictable events of this person will be difficult to agree to buy and consume products of this brand.

The fourth hypothesis predicted the impact of boycott motivation on boycott participation. Based on the SEM calculation, this path owned a C.R. score of 2.924. In general, motivation can lead to purchase intention and satisfaction [51] [52] [53]. In the case of consumer boycott, boycott motivation can affect boycott participation intention [5] as demonstrated in this current study.

[39] differentiated two dimensions of purchase willingness into two different variables: purchase willingness and purchase unwillingness. However, in his experiment, attitude was not employed. The fifth and sixth hypotheses predicted 
the effect of attitude towards marketing communication on purchase willingness and purchase unwillingness. These paths obtained C.R. scores of 4.695 and -2.268 respectively. They showed significances and therefore, the hypotheses were accepted. These findings are parallel to previous research [35] [36] [37] that demonstrated a significant effect of attitude on purchase willingness.

The seventh hypothesis tested the impact of boycott participation on purchase willingness. This path was accepted with a C.R. score of -4.281 . Further, the last hypothesis measured the influence of boycott participation on purchase unwillingness. This path gained a C.R. score of 9.326. These two findings are in line with prior studies [17] [38] [39]. Those who participated in the boycott negatively would have a willingness to purchase and vice versa. In the study of [38], boycott participation negatively affected purchase willingness. This current study showed an innovation by splitting two dimensions of purchase willingness into two different variables. The indicators that were indicating anti-purchase (the second dimension) were to represent purchase unwillingness. This experiment supports the study of [39].

\section{CONCLUSION}

In the setting of Muslim consumer boycott towards a national bread brand, this study aimed to measure the impact of animosity towards a national bread brand on boycott motivation, boycott participation, attitude towards marketing communication, and purchase unwillingness. This study found a significant effect of animosity on boycott motivation, boycott participation, and attitude towards marketing communication. Further, there was a considerable impact of boycott motivation on boycott participation. Additionally, there was a significant impact of attitude towards marketing communication and boycott participation on purchase unwillingness.

This study filled up the gap of employing attitude towards marketing communication in the literature of consumer boycott. Another innovation brought by this current research is splitting purchase willingness into purchase willingness and purchase unwillingness as suggested by the results of exploratory factor analysis. Also, by choosing a bread product as the research object involving Muslim consumers. However, this study has some weaknesses. First, the authors select participants by way of non-probability, this makes the results of this study cannot generalise Muslim consumers in general. Second, the participants were not selected based on their experience following the protests.

Observing what has happened since the bread producer announced a clarification, this can be a lesson for other companies. First, facing angry consumers, let alone the thousands, do not have to face consumers directly. The wise thing is to meet the opinion leader. From the various mass media coverage, there is indeed an opinion leader's interference in the case faced by Sari Roti in mobilising the masses to boycott. Therefore, community relations managers should be able to actively take care of misunderstandings before the matter becomes big or bigger. Secondly, the company must understand the local culture and its changes. Consumers whose anger is wrapped in religious issues will not be the same as consumer anger protecting the ocean from oil spills or animal-loving consumers against companies or communities that allow animal killings.

[54] treated animosity as a dependent variable. However, in other many studies, animosity is always treated as an independent variable [8] [55], including in this current study. Future research might exercise animosity as a mediating variable for broadening the literature of consumer boycott. Future study can also adapt or adopt the ideas brought by this current study into different objects of the boycott.

\section{REFERENCES}

[1] Wulandari, D. 2016. Blunder of Public Relations towards \#AksiSuperDamai212 (in Bahasa Indonesia). Marketing Communication [Online]. Retrieved http://mix.co.id/headline/blunder-pr-sari-rotiterkait-aksisuperdamai212. Accessed on 12 May 2018.

[2] Wang, Z., Lee, A. \& Polonsky, M. 2016. Egregiousness and boycott Intensity: Evidence from the BP Deepwater Horizon oil spill. Management science.

[3] Akbulut, A. 2014. Conflict in the global age: The case of Danish cartoon crisis. European Scientific Journal, ESJ, 10(14).

[4] Yunus, A. M., Ghani, A. A., Man, S., Mohamad, M. \& Wan Mohd, Y. W. C. 2013. An analysis of Fiqh al-Waqi' (an understanding of contemporary problems) on the ruling of compulsory boycott of KFC (Malaysia). International Journal of Humanities and Social Science, 3(1): 194-202.

[5] Suhud, U. 2016. Indonesian consumers against Israeli products: Animosity on product judgment, motivation, and boycott intention. Paper presented at the The 1st International Conference on Economics, Education, Business, and Accounting (ICEEBA 2016), Semarang.

[6] Skovgaard, J. 2018. Renegotiating responsibility: British anti-apartheid consumer boycott campaigns, late 1960s to early 1990s. Københavns Universitet, Det Humanistiske Fakultet.

[7] Klein, J. G. Ettenson, R., \& Morris, M. D. 1998. The animosity model of foreign product purchase: An empirical test in the People's Republic of China. Journal of marketing, 62(January): 89-100.

[8] Zafar, Ahmed \& Anang, Rosdin \& Othman, Md Nor \& Sambasivan, Murali. (2013). To purchase or not to purchase US products: Role of religiosity, animosity, and ethno-centrism among Malaysian consumers. Journal of Services Marketing. 27. 10.1108/JSM-01-2012-0023.

[9] Albayati, M. S., Mat, N. K. N., Musaibah, A. S., Aldhaafri, H. S. \& Almatari, E. M. 2012. Participate In boycott activities toward Danish products from the perspective of Muslim consumer. American Journal of Economics, Special issue, 120-124.

[10] De Nisco, A., Mainolfi, G., Marino, V. \& Napolitano, M. R. 2013. The influence of animosity, consumer ethnocentrism and country image perception on product receptivity. A survey on Italian consumers. Service dominant logic, network and systems theory and service science: Integrating three perspectives for a new service agenda. Napoli: Giannini. ISBN, 643849263.

[11] Ungulaityte, V. 2015. The effect of ethnocentrism and animosity on consumer purchase intentions in the food product sector in Lithuania. (Master), ISM University of Management and Economics, Vilnius, Lithuania.

[12] Mrad, S. B., Mangleburg, T. F. \& Mullen, M. R. 2014. Do consumers forgive? A study of animosity in the MENA region. Journal of International Consumer Marketing, 26(2): 153-166.

[13] Granström, J. 2014. Consumer motivations to boycott: Focus on nongreen products. (Master), Aalborg University, Aalborg. 
[14] Klein, J. G. Smith, N. C., \& John, A. 2002. Exploring motivations for participation in a consumer boycott. In S. M. Broniarczyk \& K. Nakamoto (Eds.), NA - Advances in Consumer Research 29: 363-369. Valdosta, GA: Association for Consumer Research.

[15] Shin, J., Kim, S. \& Yoon, J. 2012. Effect of sustainability management at coffee houses on customers' store image and behavioral intention. Korean Journal of Community Nutrition, 17(4): 494-503.

[16] Suhud, U. 2017a. Animosity of Indonesian consumers against foreign products. Paper presented at the The 29th International Business Information Management Association (IBIMA) Conference, Vienna, Austria.

[17] Suhud, U. 2018. The impact of consumer animosity on purchase unwillingness in a boycott of Sari Roti. Binus Business Review, 9(2): 8794.

[18] Akpoyomare, O. B., Adeosun, L. P. K. \& Ganiyu, R. A. 2012. Consumer motivations for participation in boycotts. Business and Management Review 2(9): 1-8.

[19] Braunsberger, K. \& Buckler, B. 2009. Consumers on a mission to force a change in public policy: A qualitative study of the ongoing Canadian seafood boycott. Business and Society Review, 114(4): 457-489.

[20] Hendel, I., Lach, S. \& Spiegel, Y. 2017. Consumers'activism: The cottage cheese boycott. The RAND Journal of Economics, 48(4): 9721003.

[21] Shin, S. \& Yoon, S. W. 2018. Consumer motivation for the decision to boycott: The social dilemma. International Journal of Consumer Studies (accepted article).

[22] Barakat, A. \& Moussa, F. 2017. Using the expectancy theory framework to explain the motivation to participate in a consumer boycott Journal of Marketing Development and Competitiveness, 11(3): 32-46.

[23] Melewar, T. C. 2003. Seven dimensions of corporate identity. A categorisastion from the practitioners' perspectives. European Journal of Marketing, 40(7/8): 846-869.

[24] Villarejo-Ramos, A. F. \& Sanchez-Franco, M. J. 2005. The impact of marketing communication and price promotion on brand equity. Journal of Brand Management, 12(6), 431-444.

[25] Chan, K., Li, L., Diehl, S., \& Terlutter, R. 2007. Consumers' response to offensive advertising: a cross cultural study. International Marketing Review, 24(5): 606-628.

[26] Cyril De Run, E., Mohsin Butt, M., Fam, K.-S. \& Yin Jong, H. 2010. Attitudes towards offensive advertising: Malaysian Muslims' views. Journal of Islamic Marketing, 1(1): 25-36.

[27] Waller, D. S. 1999. Attitudes towards offensive advertising: an Australian study. Journal of Consumer Marketing, 16(3): 288-295.

[28] Shyan Fam, K., Waller, D. S. \& Zafer Erdogan, B. 2004. The influence of religion on attitudes towards the advertising of controversial products. European Journal of Marketing, 38(5/6): 537-555.

[29] Friedman, M. 1999. Consumer boycotts: Effecting change through the marketplace and media. New York: Routledge.

[30] Dekhil, F., Jridi, H. \& Farhat, H. 2017. Effect of religiosity on the decision to participate in a boycott: the moderating effect of brand loyalty-The case of Coca-Cola. Journal of Islamic Marketing, 8(2).

[31] Jeon, H.-R. \& Seo, J.-H. 2015. Relevance between consumer boycott participation and perception types on the consumer boycotts. Family and Environment Research 53(2): 143-155.

[32] Cui, Y. H. \& Choo, H. J. 2013. Effects of Chinese consumers' ethnocentrism and animosity on brand attitude. Journal of the Korean Society of Clothing and Textiles, 37(7): 894-906.

[33] Durvasula, S. \& Lysonski, S. 2008. How offshore outsourcing is perceived: Why do some consumers feel more threatened? Journal of International Consumer Marketing, 21(1): 17-33.

[34] Alden, D. L., Kelley, J. B., Riefler, P., Lee, J. A. \& Soutar, G. N. 2013. The effect of global company animosity on global brand attitudes in emerging and developed markets: Does perceived value matter? Journal of International Marketing, 21(2): 17-38.

[35] Voon, J. P., Ngui, K. S. \& Agrawal, A. 2011. Determinants of willingness to purchase organic food: An exploratory study using structural equation modeling.
[36] Barber, N., Taylor, C. \& Strick, S. 2009. Wine consumers' environmental knowledge and attitudes: Influence on willingness to purchase. International Journal of Wine Research, 1(1): 59-72.

[37] Liao, C.-H. \& Hsieh, I.-Y. 2013. Determinants of consumer's willingness to purchase gray-market smartphones. Journal of Business Ethics, 114(3): 409-424

[38] Shah, K. A. M. \& Ibrahim, H. I. 2016. The impact of consumer boycott, ethnocentrism and patriotism in Malaysia. The Social Sciences, 11(19): $4622-4627$.

[39] Suhud, U. 2017b. Purchase unwillingness and willingness of Indonesian consumers towards Israeli products. Binus Business Review, 8(3): 175182.

[40] Nakos, G. E. \& Hajidimitriou, Y. A. 2007. The impact of national animosity on consumer purchases: The modifying factor of personal characteristics. Journal of International Consumer Marketing, 19(3): 5372 .

[41] Tian, S. 2010. Buy or boycott? An examination of mediated consumer animosity effects on purchase intention ( $\mathrm{PhD}$ Thesis), University of Alabama, Alabama.

[42] de Run, E. C. 2005. Attitude towards the ad: Assessing measurement invariance In cross-ethnic research. Paper presented at the ANZMAC 2005 Conference: Marketing in International and Cross-Cultural Environments, Perth.

[43] Klein, J. G. Smith, N. C., \& John, A. 2000. Why we boycott: Consumer motivations for boycott participation and marketer responses. Journal of marketing, 68(3): 92-109.

[44] Hair Jr., J. F. Black, W. C., Babin, B. J., Anderson, R. E., \& Tatham, R. L. 2006. Multivariate data analysis $(6$ ed.). New Jersey: Prentice-Hall, Inc.

[45] Schermelleh-Engel, K., Moosbrugger, H. \& Müller, H. 2003. Evaluating the fit of structural equation models: Tests of significance and descriptive goodness-of-fit measures. Methods of Psychological Research Online, 8(2): 23-74.

[46] Tabachnick, B. G. \& Fidell, L. S. 2007. Using multivariate statistics (5 ed.). Boston Pearson/Allyn \& Bacon.

[47] Hu, L.-t. \& Bentler, P. M. 1995. Evaluating model fit. In R. H. Hoyle (Ed.), Structural equation modelling. Concepts, issues, and applications, 76-99. London: Sage.

[48] Suhud, U., \& Syabai, N. (2014). Halal sex tourism in Indonesia: understanding the motivation of young female host to marry with middle eastern male tourists. J Eco Sustain Dev, 5, 91-94.

[49] Campo, S. \& Alvarez, M. D. 2017. Consumer animosity and affective country Image. In C. A., K. M., G. J., \& F. A. (Eds.), Co-Creation and Well-Being in Tourism. Tourism on the Verge, 119-131. Cham: Springer.

[50] Schiffman, L. G. \& Wisenblit, J. 2015. Consumer behaviour. New Jersey: Pearson Education, Inc.

[51] Nwankwo, S., Hamelin, N. \& Khaled, M. 2014. Consumer values, motivation and purchase intention for luxury goods. Journal of Retailing and Consumer services, 21(5): 735-744.

[52] Stefany, S. 2014. The effect of motivation on purchasing intention of online games and virtual items provided by online game provider. CommIT (Communication and Information Technology) Journal, 8(1): 22-27.

[53] White, C. 2015. The impact of motivation on customer satisfaction formation: a self-determination perspective. European Journal of Marketing, 49(11/12): 1923-1940.

[54] Akdogan, M. S., Ozgener, S., Kaplan, M. \& Coskun, A. 2012. The effects of consumer ethnocentrism and consumer animosity on the repurchase intent: The moderating role of consumer loyalty. Emerging Markets Journal, 2(1): 1-12.

[55] Čičić, M., Brkić, N. \& Prašo-Krupalija, M. 2003. Consumer animosity and ethnocentrism in Bosnia and Herzegovina: The Case of a developing country in a post-war time. Akademija MM, 6(10): 59-67. 